\title{
Pottery production and trades in Tamil Nadu region: new insights from Alagankulam and Keeladi excavation sites
}

\author{
E. Odelli ${ }^{1,2}$, T. Selvaraj ${ }^{3}$, J. Perumal ${ }^{3}$, V. Palleschi ${ }^{4}$, S. Legnaioli ${ }^{4}$ and S. Raneri ${ }^{4,5^{*}}$ (1)
}

\begin{abstract}
This research is part of a wider scientific Italian-Indo project finalised to shed lights on pottery fabrication and trade circulation in Tamil Nadu region during Early Historical Period. The recent archaeological excavations carried out in Alagankulam — a famous harbour trading with the eastern and western world — and in Keeladi-the most ancient civilization centre attested in Tamil Nadu region_- provided numerous fragments of archaeological ceramics. The typological analysis enabled the identification of different pottery classes, suggesting the presence of local productions, possible imports and imitations. Studied shards included common Indian vessels, fine wares and luxury ware repertoire. The provenance identification of some of the studied typologies is still debated in the literature; for long time, the misattribution of several ceramic classes has led to wrong interpretations on the commercial connections between India and the Western and Eastern Mediterranean area. The minero-petrographic and spectroscopic investigation of several ceramic fragments from the two investigated archaeological sites enabled the systematic compositional characterization of specific ceramic classes both locally manufactured and imported. The obtained results contributed to draw short-range and long-range connections in Tamil Nadu area.
\end{abstract}

Keywords: Tamil Nadu, Alagankulam, Keeladi, BPNW, Rouletted ware, Black and red ware

\section{Introduction}

Potteries represent one of the most useful archaeological artifacts in reconstructing human activity in the past. Being part of daily use, potteries can support the interpretation of dynamics related to trade, manufacture routines, cultural identity and artistic traditions.

The analysis of ceramic fabric, the characterization of clay composition and of the decorations (if present) can be used to locate production centers, indicate manufacture routines, interpret the progress of technology and the modes of consumption of a site [1-3]. Petrographic observations, mineralogical analysis and spectroscopic investigations are only few among the numerous

\footnotetext{
*Correspondence: simona.raneri@pi.iccom.cnr.it

${ }^{4}$ National Research Council, ICCOM-CNR, Via G. Moruzzi 1, 56124 Pisa, Italy

Full list of author information is available at the end of the article
}

scientific methods able to examine the material nature of ceramic materials and answer to archaeological and anthropological research questions $[4,5]$.

Provenance studies can contribute to the reconstruction of trade routes in ancient areas; this is particularly relevant in studying harbour cities, where commercial contacts and social activities promoted the commercialization of goods and cultural exchanges [6].

An interesting example in the light of the archaeological and historical researches in Tamil Nadu region (India) is the Alagankulam harbour; it was one of the main entrepôt of South-India in antiquity. Recent archaeological excavations carried out in Tamil Nadu region enabled to explore new structures and archaeological records in this famous city; moreover, the first settlement of the ancient civilization in Tamil Nadu-the Keeladi villagewas discovered and explored in the proximity of the Vaigai River. 
The two archaeological sites were rather close to each other and built in the proximity of the same river; however, their economic and socio-cultural organization were different. Alagankulam was a very active trade centre where local products credibly co-existed with longrange imported goods; in fact, several pottery fragments were found in the site during the new excavation campaign, including transport vessels, jars, common ware (e.g. black-and-red ware), and fine table ware (e.g., rouletted ware, black ware, Fine Grey potteries, Northern black polished ware). On the contrary, in Keeladi only few shapes were found; they mainly consist of domestic vessels, common wares (e.g., black-and-red ware and coarse red ware) and of red slipped wares.

The different ceramic classes found in the two sites can be used to define their context and chronology. Blackand-red ware (BRW) represents a class of artefacts generally attributed to the ancient Indian tradition (since the beginning of the I millennium B.C.); the name is related to its appearance, which is red and back in colour. According to the literature, black-and-red ware was produced by positioning upside down the vessels in the kiln with vegetal materials inside; the outside part, was subjected to oxidizing condition and turned in red, while the inner surface and the rims, under reducing conditions, turned in black [7]. This class of vessels is largely attested in several site through India and it is characterised by a variability in fabric and manufacture technology in respect to the production area [8]. Black ware (BW) is a class of vessels largely attested in India from the first half of the I millennium and had a lost-lasting tradition [9]; similarly to black-and-red ware, black ware is attested with various fabrics, according to the local raw materials used for its production.

Northern Polished Black Ware (NPBW) represents a class of vessels largely found through India; it is considered part of the luxury ware repertoire. Its production spread just after the so called Gray Painted Ware culture and it is traditionally located in the area of the Ganga Plains [10]. Regarding the periodization, a recent archaeological and stratigraphic revision dated the NPBW production between the VII B.C. and the I B.C. $[10,11]$. NPBW is characterized by a lustrous black slip glossy surface; this was obtained in the Indian tradition by the application of a refined clay slip and an organic liquid on the vessel, thus fired under reducing kiln conditions [11, 12].

Fine Grey Potteries represent a class of very fine and luxurious sherds largely attested in India and only recently recognized as imports from the Northern Indian areas [13-21]. For long time, these vessels were interpreted as Roman productions [20,21]; the misattribution was due to their fine quality, their slipped fabric (red or black) [21] and their wide distribution in Sri Lanka and eastern India, in the far East (e.g., in Indonesia), in Egypt, and in Bernike harbour. Fine Grey Potteries include, among other types, rouletted ware (RW) and red polished ware (RPW). Rouletted ware (RW) is characterized by an hard-glossy surface and a compact clay paste; it is easily identified by a distinct decoration pattern, due to bands of indentions with different shapes, such as lines, dots, diamonds and triangles, made by using a roulette [15]. Recent studies on rouletted ware found in Sri Lanka, Vietnam, India and reference clays from Chandraketugarh suggested the Ganges Valley as probable production centre $[16,17,20]$; in fact, its Indian provenance is currently accepted. Rouletted ware can be considered as an indicator of the intense Indian trades within the Indian Ocean and the Mediterranean regions. Rouletted ware seems to be dated between II B.C. and I A.D., before the appearance of Roman sigillata in India [13, 21]. According to the Tissamaharama pottery sequence and the recent periodization proposed by Schenk [13], it circulated for a limited time-interval (in Tissamaharama the first fragment is dated II B.C.), specifically till the I B.C. Its circulation promoted the production of later local imitations differing from the genuine ones for their coarse-grain clay paste. Red polished ware (RPW) includes typical shapes consisting in ritual vessels (i.e., spouted jugs and sprinklers) and is characterized by a fine quality red slip. It was for long time misinterpreted as Roman import due to the similarities with the well-known terra sigillata. However, recent researches and discoveries along the Persian Gulf enabled its attribution to Indian production, making it possible to consider red polished ware as an indicator of connections within the Indian Ocean at the Periplus-time [13]. Among the Indian findings, sigillata ware is the most debated ceramic class; its occurrence and identification are largely questioned since the Wheeler discoveries at Arikamedu [14], and the Begley's reconsiderations [15]. To date, the attribution of sigillata ware has to be evaluated with caution; in fact, several sigillata productions attested in different periods were traded to India, such as the Italian sigillata, the Eastern Sigillata A (from Syria) and the Eastern Sigillata B (from Western Asia Minor). Thus, the attribution of sigillata ware needs a careful examination of the archaeological context and the dating of pottery sequence.

The Indian Ocean thus represented one of the most active hubs of ancient trade [22]. Several studies described the extent of numerous commercial and social exchanges in several harbours and entrepôt along the Indian Ocean costs [23-29]. However, only few contributes provided analytical reference data on potteries for the definition of compositional reference groups [29-34]. This study aims to enlarge knowledge on pottery 
fabrication and trade circulation in Tamil Nadu region by analysing potteries from the Alagankulam and Keeladi sites. The archaeological records were analysed by minero-petrographic, chemical and spectroscopic methods. The obtained results enabled the characterization of ceramic fabrics and the reconstruction of exchanges in Tamil Nadu area, getting the basis for a reference database of Indian Tamil productions.

\section{Archaeological framework}

Alagankulam was the official harbor of the Pandya Kingdom in Madurai, in Tamil Nadu region (Fig. 1). According to the local inscriptions (Sangam literature) and some Roman authors such as Strabo (25 B.C.) and Pliny (75 B.C.), the Pandya established an intense trade and commercial relations with the Mediterranean area since the II century B.C. The archaeological excavations carried out in Alagankulam by the State Archaeological Department of Tamil Nadu in 2005 brought to the light numerous ceramic records mainly consisting in fine ware and transport vessels, among which local productions, possible imitations and imports were documented. Based on the radiocarbon dating of the strata (State Archaeological Department, Tamil Nadu, personal communication) the occupancy of the site is attested since IV-III century B.C.; the more recent excavated strata are dated to the I century B.C.-I century A.D.

Keeladi is located $12 \mathrm{~km}$ southeast of Madurai and $2 \mathrm{~km}$ from the Vaigai River, on its northern side (see Fig. 1). It is an archaeological center dated back to Sangam Era and it is considered one of the most ancient civilization centers in Tamil Nadu region. The site was extensively excavated by the State Archaeological Department of Tamil Nadu in 2017 with the exploration of 15 trenches excavated along their stratigraphy.

As far as the chronology (State Archaeological Department, Tamil Nadu, personal communication), the first occupancy of the site is dated to VI-V century B.C., while the more recent strata are dated to the II-I century B.C.

\section{Materials and Methods}

\section{The analysed ceramic corpus}

In this study twenty-nine pottery fragments representative of different typological classes have been selected and analysed: twelve samples from Alagankulam site (labelled as A_\#, Fig. 2, Table 1) and seventeen from Keeladi archaeological site (labelled as K_\#, Fig. 3, Table 1).

The fragments selected from the Alagankulam corpus are representative of the different table ware typologies found in the excavation; they consist in black rouletted ware (RW, A15), sigillata ware (A16), grey ware (GW, A17), black ware (BW, A18), red roulette ware (RW, A19), red ware (RDW, A20), black-and-red ware (BRW, A21), northern black polished ware (NBPW, A22). They were found in strata dated between the II B.C. to the I A.D.; shapes are mainly table bowls [35].

From Keeladi, two main classes were identified: coarse red ware (K1, K4, K5, K6, K11, K12) and black-and-red table ware (K3, K7, K8, K9, K10, K13, K14, K15, K17), both interpreted as Indian productions. Coarse red ware is characterised by jars with narrow and short neck and globular body; on the contrary, black-and-red ware includes open shapes consisting in simple forms as table bowls with incurved rims [8]. Only two examples of red polished ware (K2, K16) are attested; they consist in a bowl and a small jar, respectively.

Looking at the stratigraphy, black-and-red ware is testified along the entire excavated strata (from the $\mathrm{V}$ to the II-I century B.C.), coarse red ware is attested in the strata dated back to III-II century B.C., while red-slipped ware is attested only in the later phases (III-I century B.C.).

\section{Experimental}

The mineralogical and petrographic characteristics were recorded by thin section analysis by using a light microscope. Potteries were described according to Whitbread method [36] enabling the classification of different fabrics discriminated for clay matrix, microstructure and aplastic fraction features. X-ray diffraction (XRD) analyses were performed to investigate the bulk mineralogical composition; diffraction patterns were collected on a selection of thirteen powdered samples, representative of the identified petrographic fabrics. A Bruker D2 PHASER operating with $\mathrm{Cu}-\mathrm{K} \alpha$ radiation at wavelength of $1.5406 \AA$ was used; spectra were collected in the range of $01^{\circ}-70^{\circ} 2 \theta$. Non-destructive spectroscopic investigations were carried out on fresh cut surface by using the Bruker ELIO portable ED-XRF spectrometer equipped with an SDD detector and an X-Ray tube with Rhodium anode. The measuring spot on the surface is about $1 \mathrm{~mm}$ in diameter. The operational parameters were: $60 \mathrm{~s}$ acquisition time, $20 \mathrm{keV}$ tension and a current of $80 \mu \mathrm{A}$. To ensure the repeatability of the experiment, two different points on the bulk have been measured for each sample. The portable ED-XRF instruments cannot detect light elements preventing a full quantitative analysis; nevertheless, data enable to exploit the Fundamental Parameter Method [37] for obtaining a rough estimation of the elemental concentrations and their variation from one sample to the other. The elemental concentrations obtained with the Fundamental Parameter Method were averaged and used as input for a Principal Component Analysis.

Micro-Raman analyses were carried out on slipped surfaces by using a Renishaw In Via Spectrograph with a multichannel air-cooled CCD detector, equipped with a 


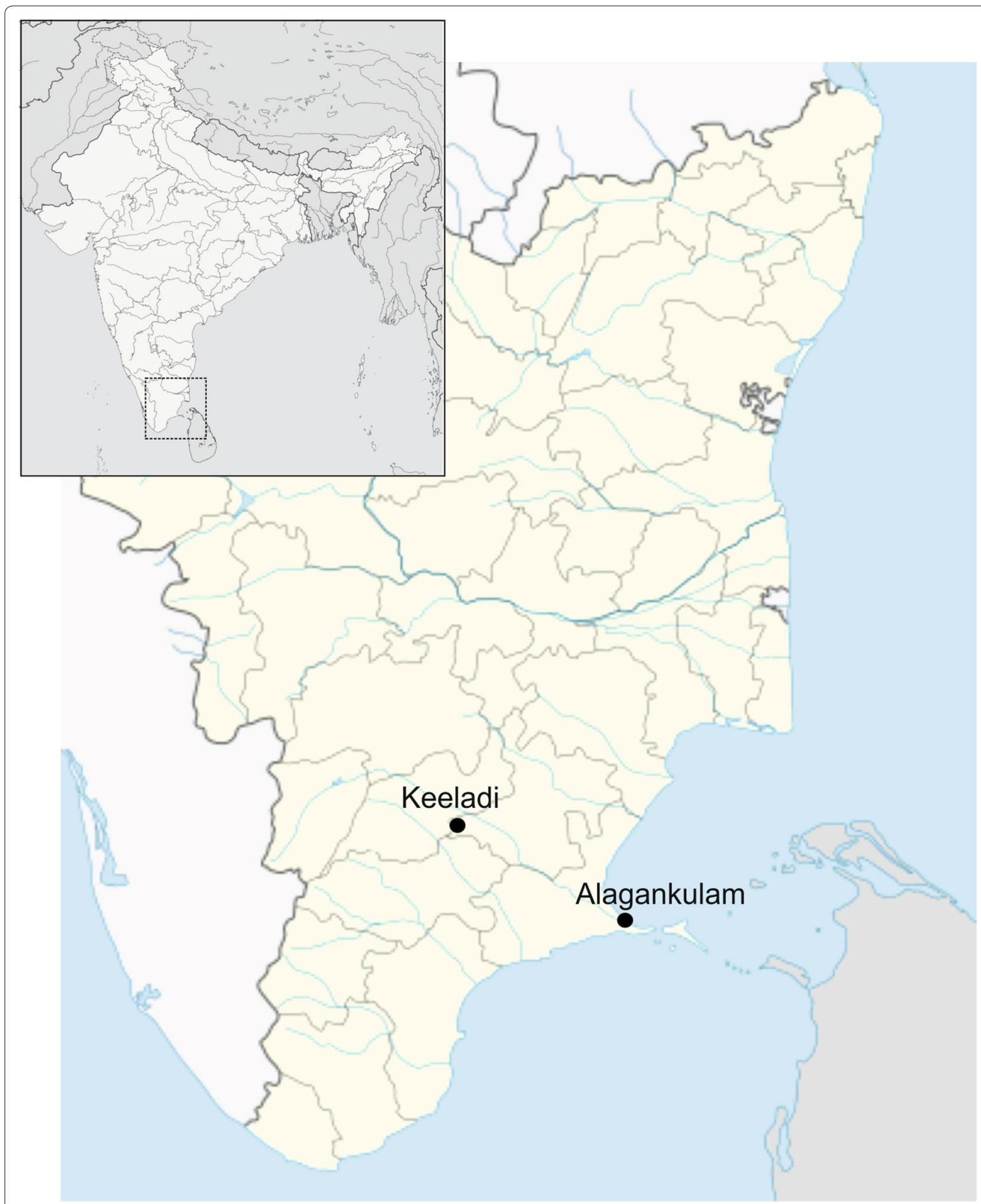

Fig. 1 Map of the south eastern India with location of the two archaeological sites 


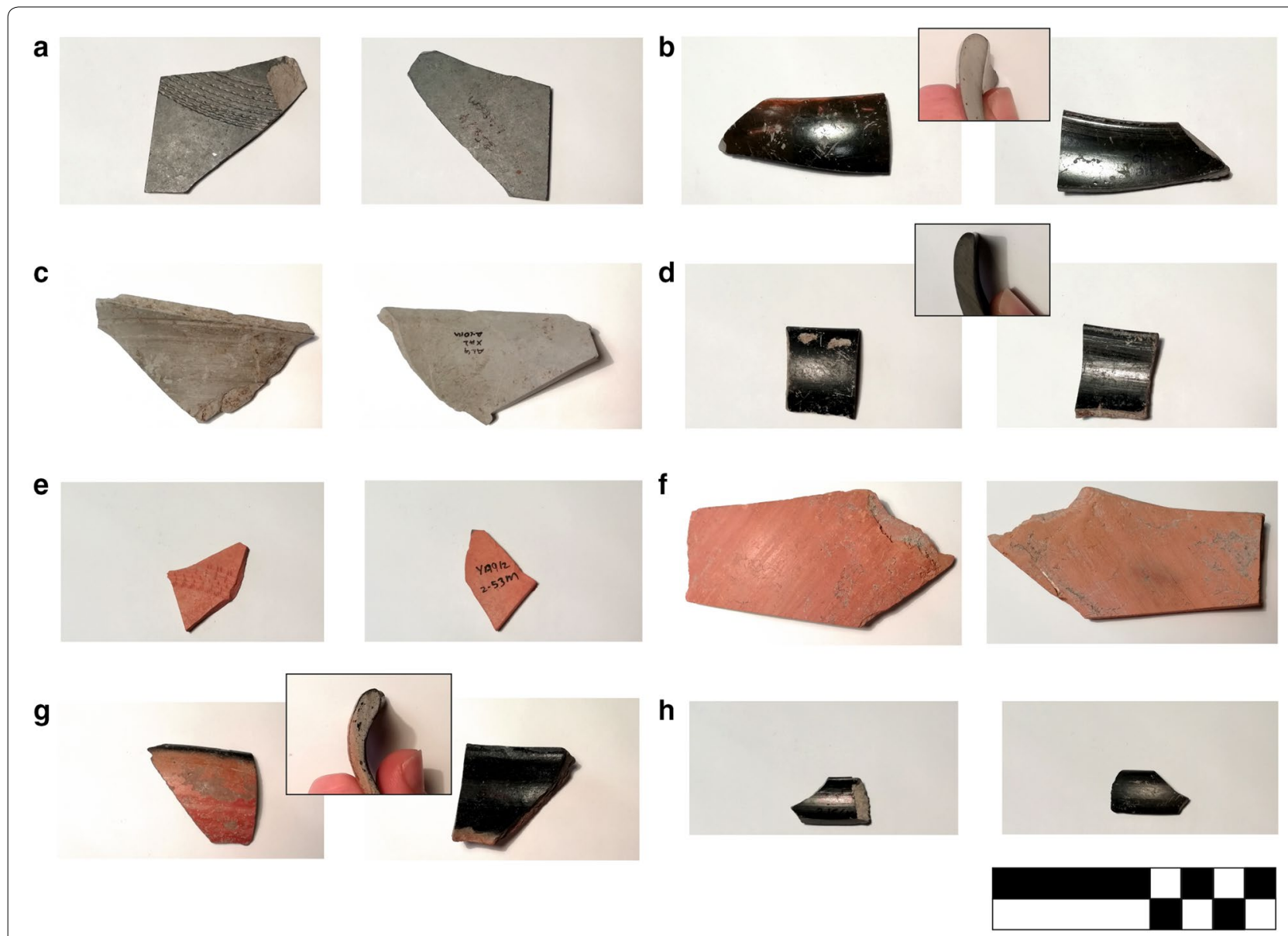

Fig. 2 Selection of pottery sherds from Alagankulam. a A15, rouletted ware (black), b A16, sigillata ware, c A17, grey ware, d A18, black ware, e A19, rouletted ware (red), $\mathbf{f}$ A20, red polished ware, $\mathbf{g A 2 1}$, black and red ware, and $\mathbf{h}$ A22, northern black polished ware

$\mathrm{He}-\mathrm{Ne}$ laser $(633 \mathrm{~nm})$ operated at the nominal power of $0.6 \mathrm{~mW}$ with an Olympus 50X objective. The spectral resolution of the instrument is about $0.5 \mathrm{~cm}^{-1}$ and the spectral range analyzed between 100 and $3200 \mathrm{~cm}^{-1}$. Typical measurements conditions were $10 \mathrm{~s}$ integration time and 10 accumulations. The laser power was set to avoid possible degradation of the sample. The spectral calibration of the instrument was performed on the $520.5 \mathrm{~cm}^{-1}$ band of a pure silicon crystal.

\section{Results and discussion}

\section{Minero-petrographic characterization}

The thin section observation carried out on potteries from Alagankulam enabled the identification of two petrographic fabrics. Fabric AGM-1 is characterized by silty and fine-grained matrix without tempers; otherwise, fabric AGM-2 is characterised by a silty ceramic paste and coarse-grained aplastic fraction.

Fabric AGM-1 (A15, A16, A17, A18, A19, A20, A22, (Fig. $4 \mathrm{a}-\mathrm{C}$ ) includes only fine-grained table ware; shards are characterised by a silty and micaceous matrix, ranging from orange (in A19 and A20) to brown-grey in colour (A15, A16, A17, A18, A22). Optical activity ranges from medium to high, absent in A16. The microstructure is the result of irregular and elongated voids, determining low porosity; some of the voids are due to fossil tests or mould. The aplastic fraction is always very fine $(<50 \mu \mathrm{m})$ and it is characterised by quartz and white mica. Amorphous concentration features (ACF) are presents; moreover, secondary recrystallization calcite is present into the bigger pores. In Fabric AGM-2 is included only one sample (A21, Fig. 4d); it is characterized by silty matrix, dark brown in colour. Optical activity is from medium to low. Microstructure is the result of elongated micropores (opening $\max <50 \mu \mathrm{m}$ ), with a preferential orientation; they are attributable fibres' residue. Rare fossils (e.g., foraminifera) are recognised in form of fossil moulds or tests. The aplastic fraction, rather abundant ( 40-50\%,), is from sub-rounded to sub-angular in shape, with polymodal grainsize distribution. It consists in fractured 
Table 1 List of analysed samples, with typology and color indication [43, 44]

\begin{tabular}{|c|c|c|c|c|}
\hline Sample No. & Site & Munsell colour (surface) & Munsell colour (bulk) & Typological classification \\
\hline A15 & \multirow[t]{8}{*}{ Alagankulam } & $7.5 Y R$ 5/1 & 7.5YR 5/1 & Rouletted ware (black) (RW) \\
\hline A16 & & $7.5 Y R 4 / 3+7.5 Y R 6 / 6$ & 7.5YR 5/1 & Sigillata \\
\hline A17 & & $7.5 Y R 6 / 1$ & $7.5 Y R$ 6/1 & Grey ware (GW) \\
\hline A18 & & $5 Y R 2.5 / 1$ & $7.5 Y R 3 / 1$ & Black ware (BW) \\
\hline A19 & & $5 Y R 6 / 8$ & $5 Y R 6 / 8$ & Rouletted ware (red) (RW) \\
\hline A20 & & $7.5 Y R 6 / 8$ & $7.5 Y R$ 6/8 & Red polished ware (RPW) \\
\hline A21 & & $5 Y R 2.5 / 1+5 Y R 5 / 8$ & $7.5 Y R 5 / 2+7.5 Y R 5 / 7$ & Black-and-red ware (BRW) \\
\hline A22 & & $5 Y R 2.5 / 1$ & $7.5 Y R 3 / 1$ & Northern Black Polished Ware (NBPW) \\
\hline $\mathrm{K} 1$ & \multirow[t]{17}{*}{ Keeladi } & $7.5 Y R$ 5/6 & $7.5 Y R 5 / 6+7.5 Y R 5 / 2$ & Coarse Red Ware (CRW) \\
\hline $\mathrm{K} 2$ & & $5 Y R 4 / 6$ & $7.5 Y R$ 6/8 & Red polished ware (RPW) \\
\hline K3 & & $5 Y R 2.5 / 1+7.5 Y R 5 / 8$ & $7.5 \mathrm{YR}$ 5/2 & Black-and-red ware (BRW) \\
\hline K4 & & $5 Y R 3 / 3$ & 5YR 4/6 & Coarse Red Ware (CRW) \\
\hline K5 & & $7.5 Y R 6 / 4$ & 5YR 5/6 & Coarse Red Ware (CRW) \\
\hline K6 & & 5YR 5/8 & 5YR 4/6 & Coarse Red Ware (CRW) \\
\hline K7 & & $5 Y R 2.5 / 1+5 Y R 4 / 6$ & $7.5 Y R 2.5 / 1+5 Y R 5 / 2$ & Black-and-red wares (BRW) \\
\hline K8 & & $5 Y R 2.5 / 1+7.5 Y R 5 / 8$ & $7.5 Y R 5 / 1+5 Y R 6 / 4$ & Black-and-red wares (BRW) \\
\hline K9 & & $5 Y R 2.5 / 1+5 Y R 5 / 6$ & $5 Y R 4 / 1+5 Y R 5 / 4$ & Black-and-red ware (BRW) \\
\hline K10 & & $5 Y R 2.5 / 1$ & $7.5 Y R 3 / 1$ & Black-and-red ware (BRW) \\
\hline K11 & & 5YR 5/8 & $5 Y R 5 / 3+5 Y R 5 / 8$ & Coarse Red Ware (CRW) \\
\hline $\mathrm{K} 12$ & & $5 Y R 4 / 6$ & 5YR 4/6 & Coarse Red Ware (CRW) \\
\hline K13 & & 5YR 5/8 & 7.5YR 2.5/1 & Black-and-red ware (BRW) \\
\hline K14 & & $5 Y R 2.5 / 1$ & 5YR 3/1 & Black-and-red ware (BRW) \\
\hline K15 & & $5 Y R 2.5 / 1+5 Y R 5 / 4$ & 7.5YR 2.5/1 & Black-and-red ware (BRW) \\
\hline K16 & & 5YR 5/8 & $5 Y R$ 5/8 + 5YR 2.5/1 & Red polished ware (RPW) \\
\hline K17 & & $5 Y R 2.5 / 1+5 Y R 5 / 6$ & 7.5YR 2.5/1 & Black-and-red ware (BRW) \\
\hline
\end{tabular}

quartz, feldspars (among which plagioclase), altered feldspars with evidences of perthite mixing, preferentially oriented micas, amphibole, pyroxenes, biotite lamellae, rare zircon, titanite, ilmenite, magnetite. Granulite rock fragments sub-angular in shape are present; they were probably smashed and intentional added as tempers.

The petrographic observation suggested the use of highly depurated clays for the shards in Fabric AGM-1; the XRD mineralogical analysis (Table 2) indicated the use of illite clays, with quartz and feldspars; unfortunately, the analysis did not evidenced diagnostic mineralogical assemblages able to provide discrimination criteria among the analysed sherds. On the contrary, the X-ray diffraction pattern collected on the black-and-red shard (A21) revealed a peculiar mineralogical suite, which is characterised by anorthite, amphibole, pyroxene, ilmenite and titanite, in accordance with the petrographic observation; a different raw materials source and technology can be thus proposed for this shard.

The analysis of the vessels from Keeladi enabled the identification of two petrographic fabrics and two singularities. The Fabric KLD-1 includes coarse red ware vessels (CRW, sample K1, K4, K5 K6, K11, K12; Fig. 5a, b). They are characterised by a silty matrix, ranging from ochre-brown to ochre in colour and with a grey core; this heterogenous aspect is attributable to a temperature gradient during firing. Optical activity is from medium to high. Microstructure is the result of elongated pores, which are from $50 \mu \mathrm{m}$ to $400 \mu \mathrm{m}$ in dimension; larger irregular voids are also present $(700 \mu \mathrm{m})$. Rare fossils (e.g., foraminifera) are present in form of moulds or tests. The aplastic fraction, rather abundant (about 40\%), is sub-rounded/sub-angular in shape; it exhibits a polymodal grainsize distribution and the dimension of grains ranges from $500 \mu \mathrm{m}$ to $1 \mathrm{~mm}$. The composition is the result of fractured quartz, feldspars (some of which exhibiting perthite mixing), plagioclase, altered feldspars, biotite lamellae, micas (exhibiting preferential orientation), amphibole, pyroxenes, titanite, ilmenite, magnetite, and rare zircon. Granulite rock fragments sub-angular in shape are present, probably smashed and intentionally added as tempers. Secondary recrystallization phases are present, along with other secondary phases related to the burial environment. Amorphous crystalline phases (ACF) and abundant clay cloths are observed. 
a

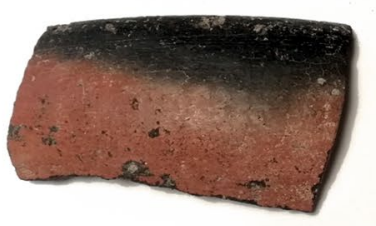

b

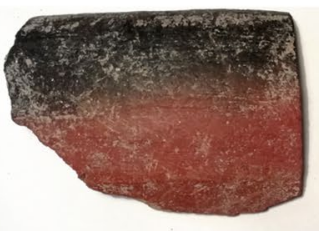

C

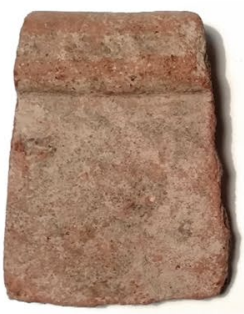

d

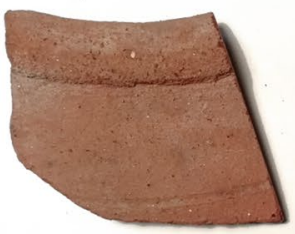

e

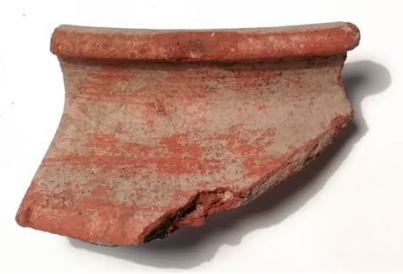

f

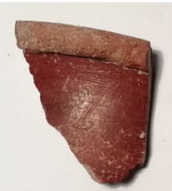

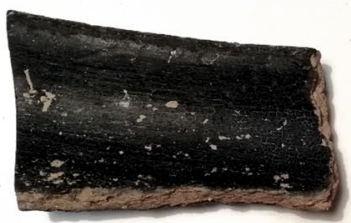
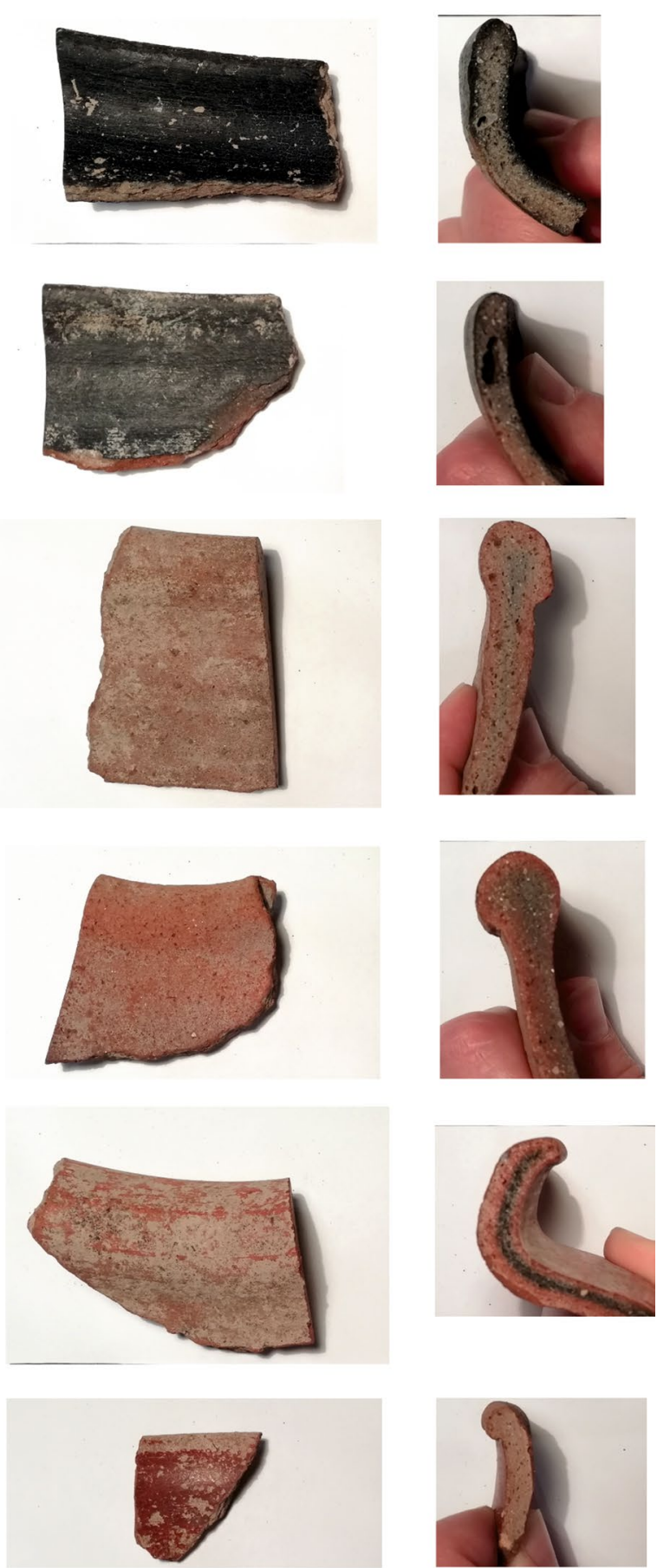

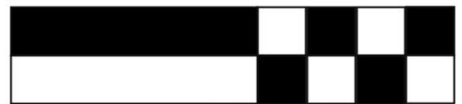

Fig. 3 Selection of pottery sherds from Keeladi. Black and red ware: a K7, b K9; Coarse red ware: c K1, d K11; Red polished ware: e K16 and f K2 
a

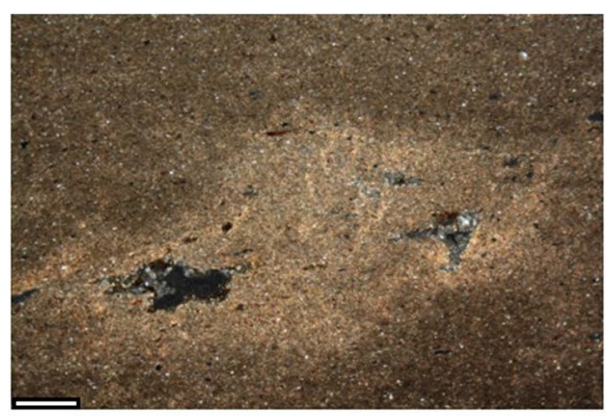

C

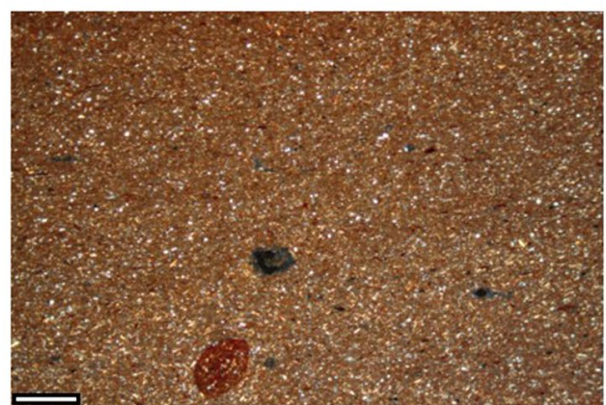

b

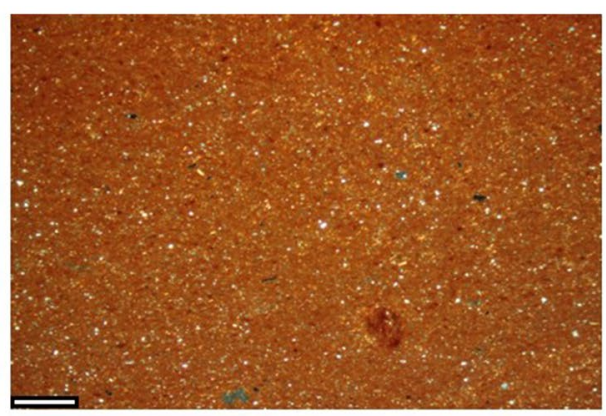

d

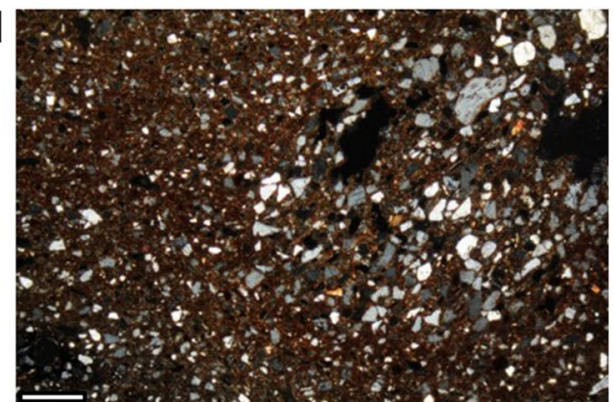

Fig. 4 Microphotographs of samples from Alagankulam representative of the two identified fabrics. Fabric AGM-1: a A18, b A19, c A20; Fabric AGM-2: d A21. Scale bar: $500 \mu m$

The samples in Fabric KLD-2 (BRW, K3, K7, K8, K9, K10, K13, K14, K15, K17; Fig. 5c, d) are black-and-red pots; shards in this fabric are characterised by silty and micaceous matrix, abundant biotite lamellae and granulite rock fragments. They differ from KLD-1 fabric in microstructure's characteristic; the aplastic grainsize is fine $(100 \mu \mathrm{m})$, the body-paste is black and they are characterised by a surface slip ranging in thickness from 50 to $500 \mu \mathrm{m}$; the microstructure is the result of irregular and elongated micropores attributable to fibres residues.

Sample K2 is a red polished ware (Fabric KLD-3, Fig. 5e); it is characterised by silty matrix, homogenous, reddish-yellow in colour, with high optical activity. Microstructure is due to elongated voids, exhibiting a preferential orientation. The aplastic fraction exhibits a polymodal grainsize distribution with granitoid rock fragments, quartz and feldspar, rare zircon and pyroxene. Abundant red amorphous phases (ACF, depletion) and recrystallization phases are present. In Fabric KLD-4 (RPW, Fig. 5f) the red polished ware K16 is characterised by clayey and micaceous matrix, orange in colour with a black core and low optical activity. Microstructure is the result of elongated and oriented micro-pores. Aplastic fraction (about 40\%) is polymodal in grain-size distribution (average $600 \mu \mathrm{m}$ ) and sub-rounded/sub-angular in shape; its composition is fractured quartz, feldspars (some of which exhibiting perthite mixing), plagioclase, altered feldspars, biotite lamellae, micas (exhibiting preferential orientation), amphibole, pyroxenes, titanite, ilmenite, magnetite, and rare zircon. Dry clay pellets were finally observed.

The mineralogical composition of Keeladi shards (Table 2) well match with the thin section observations. In fabric KLD-1 and KLD-2 the clays are characterized by illite composition and the absence of newly formed minerals; other mineral phases related to tempers were detected. These results enabled us to propose the use of not calcareous illite clays fired at low temperatures and in not-homogenous furnace conditions.

A similar mineralogical composition characterized the red polished ware labelled as K16, while slightly different mineral phases were detected in K2 sample.

\section{Chemical composition}

The multivariate statistical analysis applied on chemical data [37] (Additional file 1: Table S1) enabled the discrimination of ceramic typologies on chemical base. In Fig. 6 the first two Principal Component and the loading plots are reported. The total variance expressed by the first two components is $73.5 \%$. PC1 positive values are mainly influenced by $\mathrm{Cr}$, while negative ones by $\mathrm{Si}$; PC2 positive values are influenced by $\mathrm{K}, \mathrm{Fe}$ and $\mathrm{Ti}$, while negative values by $\mathrm{Mn}$ and $\mathrm{Ca}$. The PCA analysis discriminated two main groups: a group of samples in PC1 


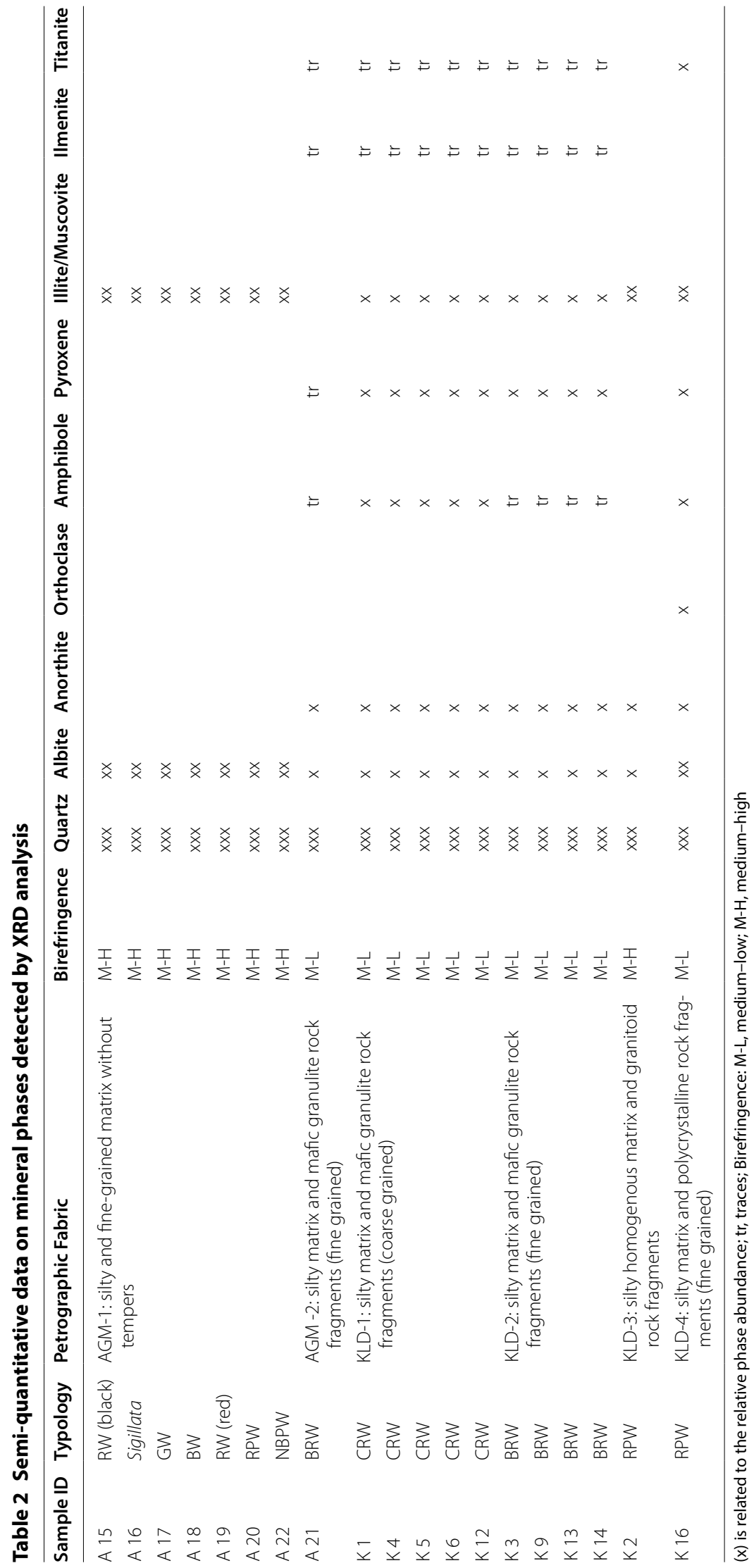


a

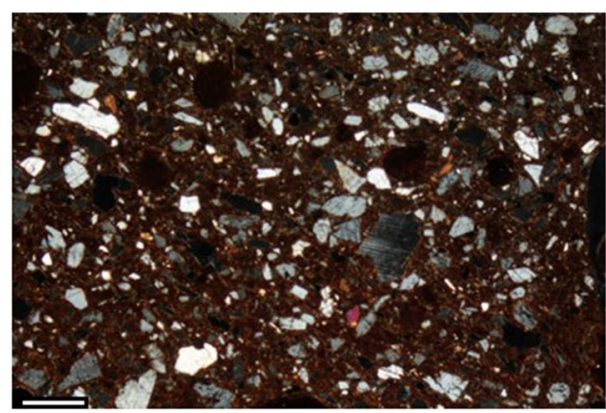

C

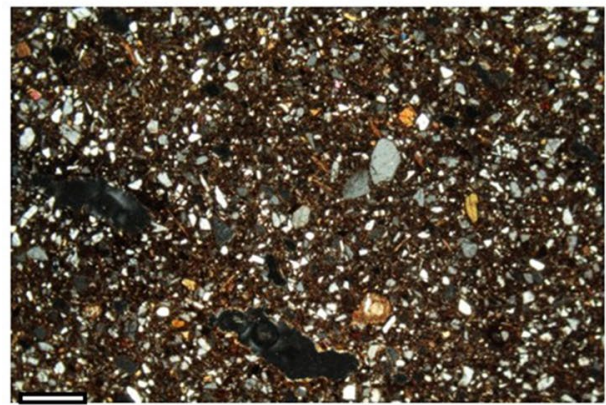

e

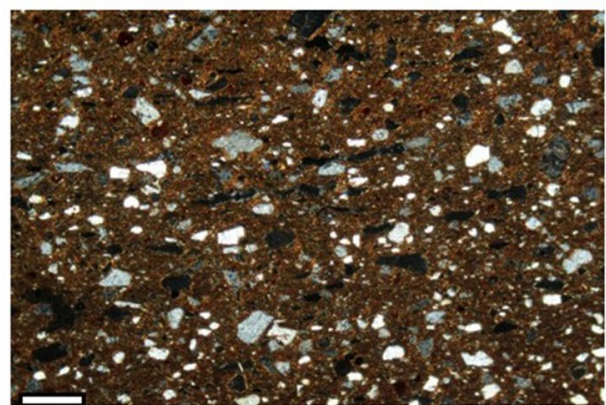

b

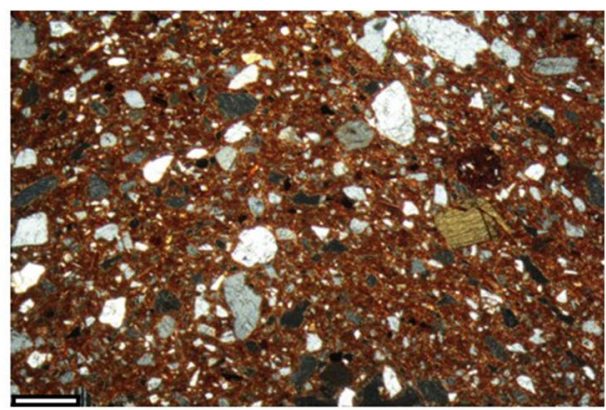

d

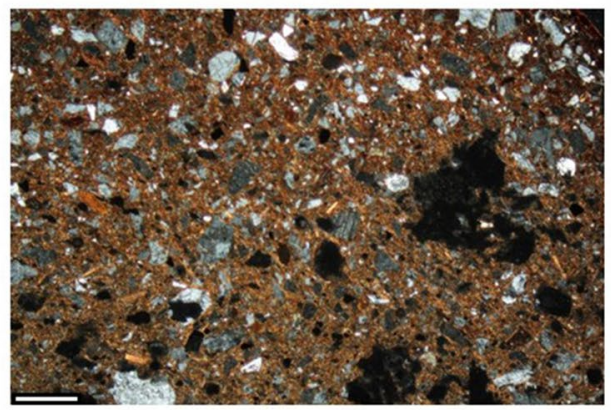

f

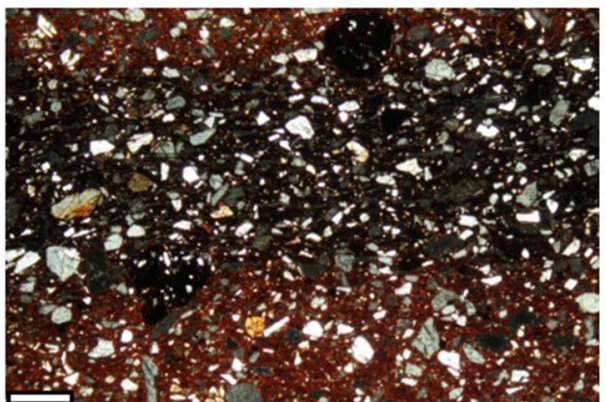

Fig. 5 Microphotographs of samples from Keeladi representative of the two identified fabrics. Fabric KLD-1: a K5, b K1; Fabric KLD-2: c K3 d K9; Fabric KLD-3: e K2, and Fabric KLD-4: f K16. Scale bar: $500 \mu \mathrm{m}$

negative direction and $\mathrm{PC} 2$ positive direction includes shards from Alagankulam, while most of the samples from Keeladi get together in $\mathrm{PC} 1$ positive direction and PC2 positive direction. This result reflects the mineralogical composition of the shards. In fact, Keeladi samples are characterized by calcite-poor clays and granulite rock fragments, except for sample K2. The PC2 further discriminated some of the shards. The K2 sample differs for its negative PC1 and PC2 values; in fact, it is characterized by different petrographic and mineralogical features. Similarly, PC2 negative values discriminate samples A17, A21 and K17. In fact, sample A21 differs from Alagankulam fine ware for its mineralogical and petrographic features; the negative PC2 values in K17 and A17 could be related to the influence of secondary calcite observed in thin section.

\section{Raman analyses on black and red surfaces}

Raman analysis was carried out on the slipped surface in black-and-red ware (Fig. 7). The analyzed black slip reveals the main peaks of amorphous carbon with characteristic absorption peaks at $1390 \mathrm{~cm}^{-1}$ and $1610 \mathrm{~cm}^{-1}$ [38]. The Raman spectra of the red slip present the intense peak at $290 \mathrm{~cm}^{-1}$ together with the medium intensity bands at $223,407,495,609$, and $1334 \mathrm{~cm}^{-1}$ characteristics of haematite [39]; weak signals attributable to quartz were detected as well. The broad band at $661 \mathrm{~cm}^{-1}$ might be assigned to magnetite trace $\left(\mathrm{Fe}_{3} \mathrm{O}_{4}\right)$, probably 

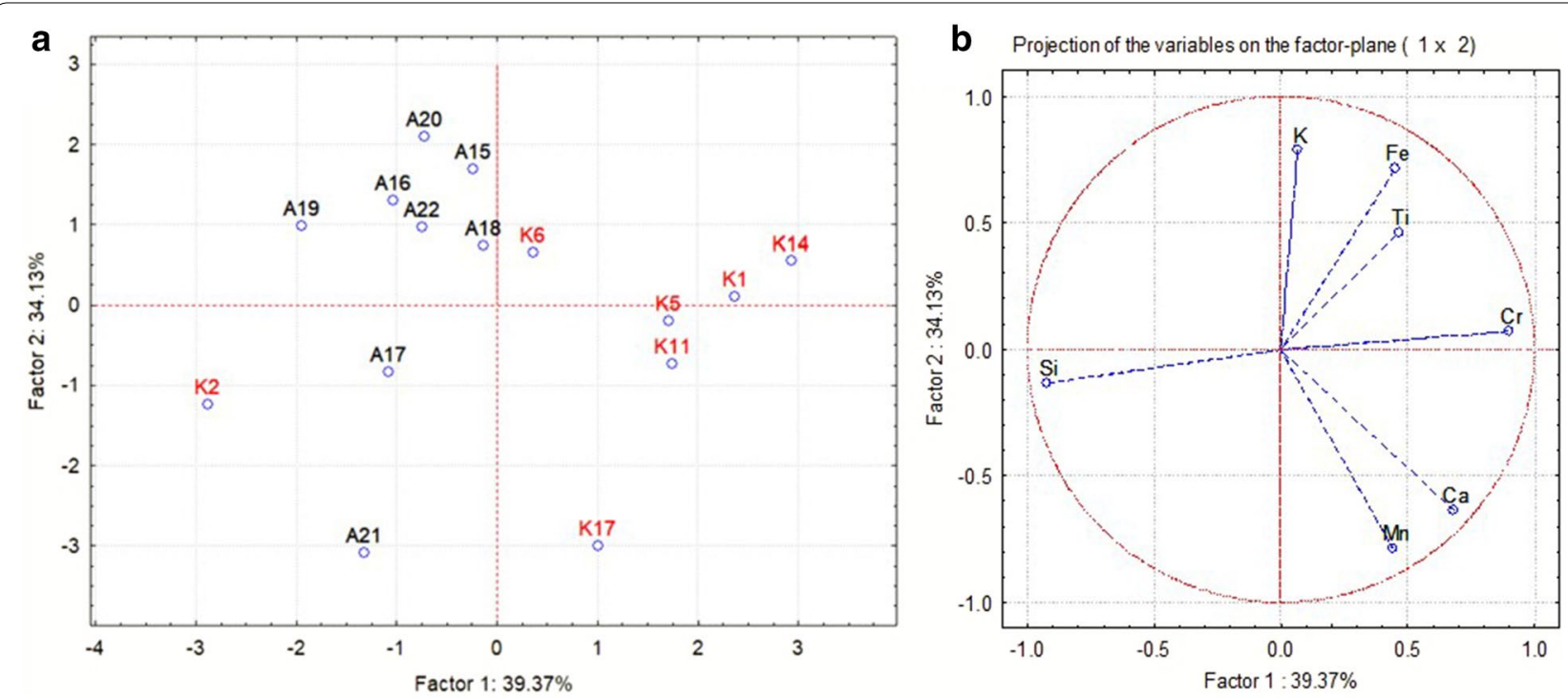

Fig. 6 Principal component analysis through detected chemical elements. Scores and loadings points are shown
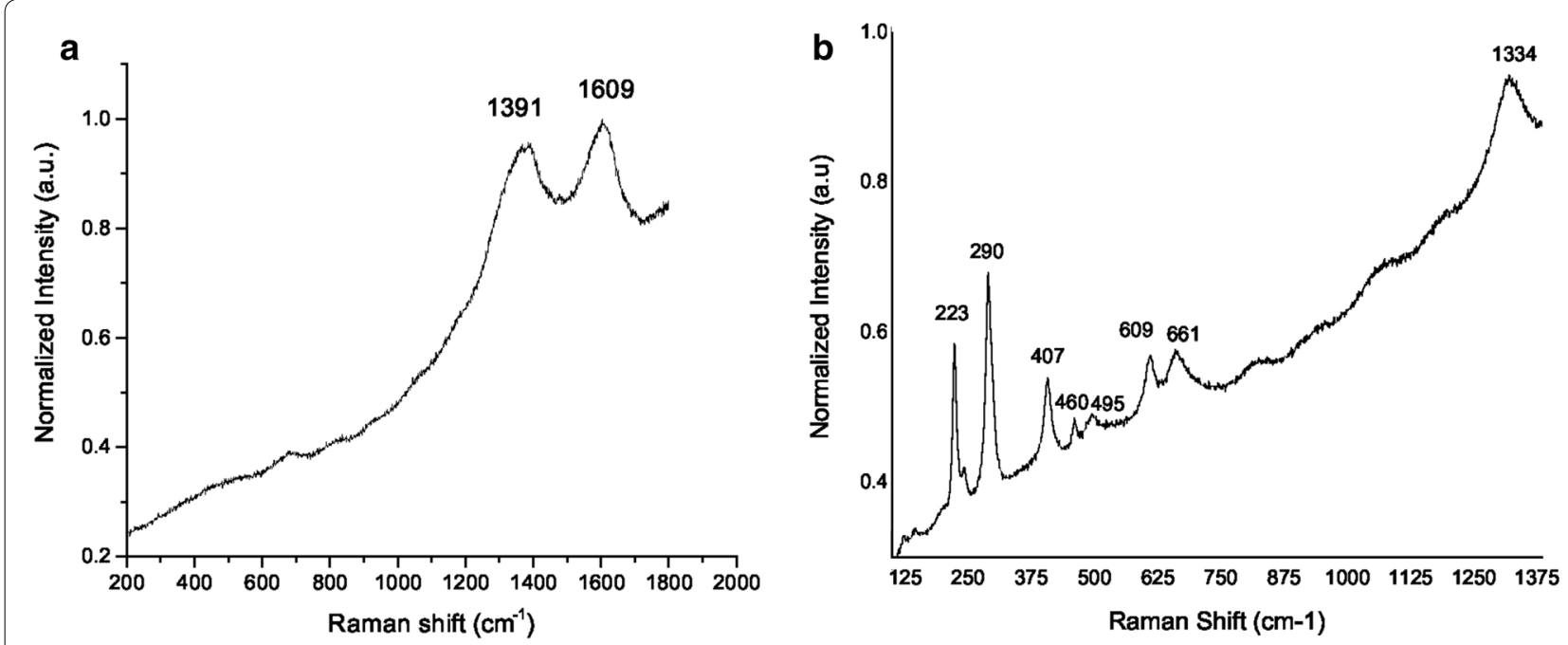

Fig. 7 Raman spectra collected on black (a) and red (b) surfaces of black-and-red ware (BRW) in K15, as example

indicating a certain reduction during firing or impurities in raw materials [40].

\section{Discussion}

Most of the potteries from Alagankulam evidenced similar compositional and textural features, i.e. fine depurated clay pastes and fine glossy surface. The petrographic observations did not provide diagnostic features; on the contrary, mineralogical and chemical analysis revealed a compositional homogeneity for most of the studied samples, which would suggest a common provenance. According to the literature, the studied fine luxury ware repertoire is interpreted as imports from the North India; however, recent studies suggested that rouletted ware were manufactured in Tamil Nadu area and exported to North India [34]. The mineralogical and chemical differences observed between this corpus and the local common ware from Keeladi would suggest that fine ware was imported in Tamil Nadu, credibly from the Northern Indian regions. It is worth of note that the sample A16, which was preliminarily identified as sigillata, it is included in this compositional field. Based on the dating, it could be interpreted as an exemplary of Eastern Sigillata $A$ which production centers were in Eastern 
Mediterranean area during Roman age (II century B.C.II century A.D.). Nevertheless, the chemical affinity with the fine ware imports would suggest a misclassification of the pottery; it could be classified as a red polished ware from the Northern Indian regions.

Black-and-red ware and coarse red ware from Keeladi are characterized by a mineralogical assemblage compatible with the local geological outcrops (i.e., pyroxene granulites and charnockite gneiss [41, 42]). This result enabled the characterization of the common ware Tamil Nadu production. The observed textural differences between the two ceramic classes could be attributed to the different function of the vessels, i.e. table bowls in black-and-red ware and storage jars in coarse red ware. The mineralogical composition of the vessels suggested the use of not calcareous illite clays and intermediate rock fragments, which is compatible with local clays geochemistry [34]. It is of interest that the shard from Alagankulam representative of the black-and-red ware (A21) found in the site can be attributed to the local Tamil Nadu production. This evidence would indicate the exchange of goods between the cost and the inland, where the local workshops were specialized in common ware fabrication. The Raman analysis carried out on the colored surfaces of the black-and-red vessels confirmed the application of the inverse firing routine; the carbon detected on the rims and on the inner surface is a residue of the vegetal materials used in the kiln and positioned inside the vessel. The technological routine used in Keeladi to produce local common ware seems to be unvaried over the archaeological stratigraphy, which indicated the convey of technology and raw material source exploitation over all the site occupancy.

Regarding the red polished ware, the literature located their production in Northern Indian sites, from Ganges Valley to Gujarat [20, 21]. However, the archaeological analysis evidenced that the import of specific typologies promoted the production of local imitations [13]; the red polished ware from Keeladi might be an example of this practice. In fact, sample K16 is compatible with the local geology, suggesting a local imitation; otherwise, sample $\mathrm{K} 2$ is characterized by granitoid rock fragments, not compatible with the local outcrops. Looking at the regional geological framework, a possible source area could be in the neighbors of Tiruchirappalli region, where granites outcrops occur [42]; it is therefore probable that local imitations produced in different location were traded in Tamil Nadu region.

\section{Conclusions}

To our knowledge, this research constitutes one among the few systematic studies on coherent corpora of ancient ceramics from Tamil Nadu. Beside the material characterization aspects, the study contributed to better understand the commercial and social relations between harbors and the inland in Tamil Nadu region. In accordance with the literature, Alagankulam was involved in several trade routes; therefore, the characterization of North Indian imports in Alagankulam enforced its role in the connective tissue of the India Ocean even prior than the Roman trades. The study further provided the characterization of the Tamil Nadu common ware fabric (black-and-red ware and coarse red ware) and testified the practice of local imitation of red polished ware. The research, still in progress, intends to support the archaeological studies on the role of Tamil Nadu in the complex commercial tissue of the Indian Ocean in antiquity. Advanced and ongoing investigations on transport vessels contributed in drawing some of the ancient trade routes established within the Indian Ocean.

\section{Supplementary information}

Supplementary information accompanies this paper at https://doi. org/10.1186/s40494-020-00402-2.

Additional file 1: Table S1. Chemical composition of the analyzed samples. Elemental concentration was estimated by Fundamental Parameters method.

\section{Abbreviation}

CRW: Coarse red ware; BRW: Black and red ware; BW: Black ware; RDW: Red ware; GW: Grey ware; NPBW: Northern polished black ware; RW: Rouletted ware; RPW: Red polished ware; XRD: X-ray diffraction; ED-XRF: Energy-dispersive X-ray fluorescence; PCA: Principal component analysis; PC: Principal component; ACF: Amorphous concentration features.

\section{Acknowledgements}

The authors acknowledge the Archaeological State Department, Tamil Nadu, and the archaeologists working at Alagankulam and Keeladi sites for having provided the studies samples. T.S. and J. P. acknowledge the Visiting Fellow program of the University of Pisa for having supported their research mobility to Italy. E.O. acknowledges the support of Tuscany Region for the "Pegaso" doctoral fellowship.

\section{Authors' contributions}

EO: investigation, data acquisition, writing —original draft, writing — review \& editing. TS: conceptualization, investigation, data curation, methodology, writing — review \& editing. JLP: investigation, data acquisition. VP: investigation, data acquisition, writing — original draft, writing — review \& editing. SL: investigation, data acquisition, writing —original draft, writing — review \& editing. SR: project administration, conceptualization, investigation, data curation, methodology, writing — original draft, writing — review \& editing. All authors read and approved the final manuscript.

\section{Funding}

Not applicable.

Availability of data and materials

All data generated or analysed during this study are included in this published article and its Additional file.

Competing interests

The authors declare that they have no competing interests. 


\begin{abstract}
Author details
1 Department of Civilization and Forms of Knowledge, University of Pisa, Pisa, Italy. ${ }^{2}$ Department of Archaeology, Ghent University, Sint-Pietersnieuwstraat 35, 9000 Ghent, Belgium. ${ }^{3}$ School of Civil Engineering, Vellore Institute of Technology, Vellore, India. ${ }^{4}$ National Research Council, ICCOM-CNR, Via G. Moruzzi 1, 56124 Pisa, Italy. ${ }^{5}$ Department of Earth Sciences, University of Pisa Via Santa Maria, 53, 56126 Pisa, Italy.
\end{abstract}

Received: 31 March 2020 Accepted: 8 June 2020

Published online: 13 June 2020

\section{References}

1. Barone $\mathrm{G}$. The mineralogical and petrographic approach to the pottery analysis at different observation scales. Plinius. 2017;43:20.

2. Quinn PS. Ceramic petrography. The interpretation of archaeological pottery and related artefacts in thin section. Oxford: Archaeopress; 2013.

3. Scarcella S. Archaeological ceramics: a review of current research British Archaeological Reports International Series S-2193. Oxford: Archaeopress; 2011

4. Tite MS. Pottery production, distribution, and consumption - the contribution of the physical sciences. J Arch Method Theory. 1999;6(3):181-233.

5. Tite MS. History of Scientific Research. In: Hunt A, editor. The Oxford handbook of archaeological ceramic analysis. Oxford: Oxford University Press; 2016.

6. Rougeulle A. A medieval trade entrepot at Khor Rori? The study of the Islamic ceramics from Hamr Al-Sharqiya. In: Avanzini A, editor. A Port in Arabia between Rome and the Indian Ocean (3rd C. BC-5th C. AD). Khor Rori Report 2. Roma: L'Erma di Bretschneider; 2008. pp. 645-667.

7. Singh U. A History of ancient and early medieval india: from the stone age to the 12th century (PB). Delhi: Pearson Education India; 2009.

8. Singh HN. History and archaeology of black and red ware hardcover. Delhi: Sandeep Prakashan; 1997.

9. Schenk $\mathrm{H}$. The dating and historical value of rouletted ware. Zeitschrift für Archäologie Außereuropäischer Kulturen. 2006;1:123-52.

10. Uesugi A. A Study on the painted grey ware, heritage. J Multidis Stud Archaeol. 2018:6:1-29.

11. Sharim D, Okada F. Surface coating technique of northern black polished ware by the microscopic analysis. Ancient Asia. 2011;3:49-65.

12. Maritan L, Nodari L, Olivieri LM, Vidale M. Shades of black: production technology of the black slip ware from Barikot, north-western Pakistan. J Cult Heritage. 2019. https://doi.org/10.1016/j.culher.2019.10.002

13. Schenk H. Role of ceramics in the indian ocean maritime trade during the early historical period. In: Tripati S, editor. Maritime contacts of the past: deciphering connections amongst communities. New Delhi: Delta Book World; 2015. p. 143-81.

14. Wheeler RE, Ghosh A, Deva K. Arikamedu: an Indo-Roman trading station on the east coast of India. Ancient India. 1946;2(2):17-24.

15. Begley V. Rouletted ware at Arikamedu: a new approach. Am J Archaeol 1988:1:427-40

16. Gogte VD. The Chandraketugarh-Tamluk region of Bengal: source of the early historic rouletted ware from India and Southeast Asia. Man Environ. 1997;22(1):69-85.

17. Gogte VD. XRD analysis of the Rouletted Ware and other fine grey ware from Tissamaharama. Ancient Ruhuna: Sri Lankan-German archaeological project in the southern province. 2001;1:197-202.

18. Coningham R, Gunawardhana P, Allchin FR. Anuradhapura: the hinterland. Oxford: Archaeopress for the society for South Asian studies; 1999.

19. Ford LA, Coningham RA, Franke-Vogt U, Weishaar HJ. Early Historic specialisation and standardisation: the technology of Rouletted ware and associated wares at Anuradhapura. In: Franke-Vogt U, Franke-Vogt HJ editors. South Asian archaeology, 2003: proceedings of the seventeenth international conference of the European association of south Asian archaeologists. Berlin: Linden Soft; 2005. p. 393-398.

20. Schenk H. Tissamaharama Pottery sequence and the Early Historic maritime Silk Route across the Indian Ocean. Zeitschrift für Archäologie Außereuropäischer Kulturen. 2014:6:95-117.

21. Tomber R, Simpson A. Indo-Roman trade: from pots to pepper. London: Duckworth; 2008.
22. Seland EH. Archaeology of trade in the Western Indian Ocean, 300 B.C.AD 700. J Archaeol Res. 2014;22:367-402. https://doi.org/10.1007/s1081 4-014-9075-7.

23. Sharma PS. Un entrepôt de commerce médiéval sur la côte du Hadramawt (Yémen, ca. 980-1180). In: Rougeulle A, editor. British Foundation for the Study of Arabia Monographs 17. Oxford: ArchaeoPress; 2015. pp. 582.

24. Rougeulle, A. The Sharma horizon: Sgraffiato wares and other glazed ceramics of the Indian Ocean trade (c. AD 980-1140). Proceedings of the Seminar for Arabian Studies. 2005; 35, pp. 223-246.

25. Rougeulle A, Benoist A. Notes on pre- and early Islamic harbours of Hadramawt (Yemen). Proceedings of the Seminar for Arabian Studies. 2001; 31, pp. 203-214.

26. Beaujard $\mathrm{P}$, Fee $\mathrm{S}$. The Indian ocean in Eurasian and African world-systems before the sixteenth century. J World History. 2005;16(4):411-65.

27. Beaujard P. From three possible iron-age world-systems to a single AfroEurasian world-system. J World History. 2010;21(1):1-43.

28. Francis P. Asia's maritime bead trade: 300 B.C. to the present. Honolulu: University of Hawaii Press; 2002.

29. Francis P Jr. Beadmaking at Arikamedu and beyond. World Archaeology 1991;23(1):28-43.

30. Naseerutheen A, Chandrasekaran A, Rajalakshmi A, Ravisankar R. Elemental analysis of ancient potteries of Vellore Dist, Tamil Nadu, India by ED-XRF technique with statistical approach. Beni-Suef Univ J Basic Appl Sci. 2014;3(1):45-51

31. Duraisamy S, Gothandapani V. Characterization and chemometric analysis of ancient pot shards trenched from Arpakkam, Tamil Nadu, India. J Appl Res Technol. 2016:14(5):345-53.

32. Magee P. Revisiting Indian rouletted ware and the impact of indian ocean trade in early historic. Antiquity. 2010;84:1043-54.

33. Ford LA, Pollard AM, Coningham RAE, Stern B. A Geochemical investigation of the origin of rouletted and other related south asian fine wares. Antiquity. 2005;79:909-20.

34. Das S, Ghosh S, Gangopadhyay K, Ghosh S, Hazra M. Provenance study of ancient potteries from West Bengal and Tamil Nadu: application of major element oxides and trace element geochemistry. Sci Total Environ. 2017;52:11-20.

35. Pavan, A. Khor Rori Report 3. A cosmopolitan city on the Arabian coast. The imported and local pottery from Khor Rori. Roma: L'ERMA di Bretschneider; 2017

36. Whitbread IK. Fabric description of archaeological ceramics. In: Hunt A, editor. The Oxford handbook of archaeological ceramic analysis. Oxford: Oxford University Press; 2017

37. Solé VA, Papillon E, Cotte M, Walter P, Susini J. A multiplatform code for the analysis of energy-dispersive $\mathrm{X}$-ray fluorescence spectra. Spectrochim Acta Part B. 2007;62:63-8

38. Lluveras-Tenorio A, Spepi A, Pieraccioni M, Legnaioli S, Lorenzetti G, Palleschi V, Vendrell M, Colombini MP,Tinè MR, Duce C, Bonaduce I. A multi-analytical characterization of artists' carbon-based black pigments. J Therm Anal Calorim. 2019:138:3287-99. https://doi.org/10.1007/s10973-019-08910-5.

39. De Faria DLA, Venâncio Silva S, De Oliveira MT. Raman microspectroscopy of some iron oxides and oxyhydroxides. J Raman Spectrosc. 1997:28:873-8.

40. Froment F, Tournié A, Colomban P. Raman identification of natural red to yellow pigments: ochre and iron-containing ores. J Raman Spectrosc. 2008:39:560-8.

41. Sajeev K, Osanai Y, Santosh M. Ultrahigh-temperature metamorphism followed by two-stage decompression of garnet-orthopyroxene-sillimanite granulites from Ganguvarpatti, Madurai block, southern India. Contrib Miner Petrol. 2004;148:29-46.

42. GSI A. Geological and mineral map of Tamil Nadu \& Pondicherry on 1: 50,000 scale. Geo Surv India, Kolkata; 1995.

43. Munsell Color (Firm). Munsell soil color charts: with genuine Munsell color chips. Grand rapids: Munsell color; 2010.

44. Ruck L, Brown CT. Quantitative analysis of Munsell color data from archeological ceramics. J Arch Sci Rep. 2015:3:549-57.

\section{Publisher's Note}

Springer Nature remains neutral with regard to jurisdictional claims in published maps and institutional affiliations. 